\title{
FOREIGN DIVERSIFICATION AND PERFORMANCE OF QUOTED DEPOSIT MONEY BANKS IN SELECTED SUB-SAHARA AFRICAN COUNTRIES
}

\author{
Osagie Osifo*, Esther Ikavbho Evbayiro-Osagie \\ Department of Banking and Finance, Faculty of Management Sciences, University of Benin, \\ Benin City, Edo State, Nigeria \\ osagie.osifo@uniben.edu \\ esther.evbayiro-osagie@uniben.edu
}

\begin{abstract}
Foreign diversification offers prospective market opportunities which afford firms prospects for greater growth and penetration of global markets. This study investigated the effect of foreign diversification on performance of quoted deposit money banks in selected Sub-Sahara African countries; Botswana, Ghana, Kenya, Malawi, Mauritius, Namibia, Nigeria, South Africa, Uganda, Zimbabwe and Zambia. The study employs secondary data collected and computed from sampled deposit money banks annual audited financial statements. Employing the use of descriptive statistics, correlation analysis, panel unit root analysis, co-integration test, multivariate panel data analysis and the system-GMM for a period of 2007 - 2017, the data were estimated with the aid of Eviews 9.0 econometric statistical package. Using dependent variables (Net interest margin and Tobin Q), explanatory variables of foreign diversification, bank's size and bank's age respectively. The findings revealed that foreign diversifications have negative and significant effect on all the performance indicators (NIM and TOBIN Q) used in the study. The explanatory variable (foreign diversification) was significant at $1 \%$ significance level. The findings from robustness check showed that the coefficients of foreign diversification are also largely negative for most of the banks. This study therefore recommends, amongst others, banks should consider diversification as a long run strategy for promoting growth and other forms of expansions. This can be achieved by promoting more regional banking integration within the sub-region. Given that formalities are already on the ground to facilitate entry and establishment within economies in the regional blocs, diversification in this direction will involve less institutional obstacles.
\end{abstract}

Keywords: System-GMM, Foreign diversification, Regional banking, Net interest margin.

JEL classification: G30, G34.

\section{Introduction}

All over the globe, businesses are establishing outlets in other areas in order to remain competitive and hedge against risk and provide more returns for their shareholders. The deposit money banks in selected sub-Sahara African countries are not left out in this new scheme of expanding their reach to their customers in other parts of the world. The urge for corporate managers to positively structure how the firm's business is conducted because corporate firms are working in milieu that are ever more vague, multifarious, aggressive, dynamic and volatile (Ojo, 2009). According to Thomson, Gamble, and Strickland (2004), the worth of decision-making strategic input, plans and implementation has an extremely affirmative effect on earnings, cash flows, and returns on investment. An appropriate strategy in the business environment has the propensity to push an organization from a

\footnotetext{
* Corresponding author: Osagie Osifo
} 
straggling situation into one in control such that the corporate organization's outputs in form of good/services becomes the industry standard.

The central key strategy engaged by corporate firms in an attempt to improve their performance is diversification. The performance of corporate firms are boosted by diversification because the existing internal and external resources are leveraged on, in order to support other ventures, thus complementing the general performance of the corporate firm. Diversification helps corporate firms build the needed exigency for enhancing shareholders value by using prior assets (Thomson et al., 2004). As documented by Ansoff (1957), diversification is manifested in diverse forms which can assume market penetration, market development and product development. Foreign diversification can be situated under market penetration owing to the fact that deposit money banks are taking their business to other areas.

Competition has increased in the banking sector due to the deregulation and liberalization witnessed in a number of countries in the last twenty years by encouraging non-banking players to join the industry (Mulwa\&Kosgei, 2016). Deposit money banks have responded to the competition pressure by raising their involvement in modern intermediation services such as investment banking and insurance and delving into other domains (real estate, oil and gas financing) that were prior tagged as risky (Gamra \& Plihon, 2011). In addition, deposit money banks have significantly expanded their outlets in domains that were prior viewed as un productive. Since universal banking system is not appealing any longer in the sub-Sahara region, owing to turbulent operating environment most deposit money banks have to resort to corporate diversification. Deposit money banks now operates in shores outside their original domicile in order to extend their services to other climes and by so doing having wider coverage and increasing their returns.

Corporate diversification and performance of deposit money banks has been largely explored from diverse methodologies such as correlation, anova, ordinary least squares simple and multiple regression analysis, panel regression analysis, data envelopment analysis and Hirschman Herfindahl index (Ojo, 2011; Ugwuanyi, \& Ugwu, 2012; Turkmen \& Yigit, 2012; Brighi \& Venturelli, 2013; Chen; Wei, Zhang, \& Shi, 2013; Meysam \& Shavazipour, 2013; Mulwa, Tarus \& Kosgei, 2015; Berg, 2016; Krivokapic, Njegomir \&Stojic, 2017). These methods are largely part of conventional techniques. Unfortunately, these approaches have their drawbacks and demerits in that they are sensitive to outliers, focuses on the mean of the dependent variables, the test statistics might be unreliable when data is not normally distributed (Feng et al., 2014). The drawback of data envelopment analysis can also include that it converges slowly to absolute efficiency i.e it is only suitable for relative efficiency and the problem of computation in regards to large decision-making units (Charnes, Cooper \& Rhodes, 1978). Thus, this study therefore intends to make use of system generalized method of moments (system-GMM) to analyse the dynamic panel data owing to its superiority in terms of efficiency, correction of endogeneity problem, measurement biases and omitted variables. The system GMM estimator is known and expected to produce less biased and more precise estimates.

The central purpose of this study is to examine the effect of foreign diversification on performance of quoted deposit money banks in selected sub-Sahara African countries. In the light of the above, the hypothesis below will be tested in this study.

(i). Foreign diversification does not significantly impact on performance of quoted deposit money banks in selected Sub-Sahara African countries.

Following this introduction, section two deals with the conceptual issues and review 0 fempirical literature on foreign diversification. Section three reviews data and methodology, while Section four gives an overview of empirical analysis and Section five will be conclusion and recommendation. 


\section{Literature Review}

Foreign diversification occurs when a firm operates in a market outside her national boundaries. Capar and Kotabe (2013), opine that foreign diversification is a growth strategy that has major influence on the firm's performance. This effect according to Ansoff (1957) is a growth strategy.

Buhner (1987) maintained that foreign diversification gives prospective market gains which afford corporate organizations avenues for increased growth. Diminution of risk works through diversification owing to the co-movements in return between diverse markets are not perfect; these unsynchronized movements between different markets mitigate volatilities in an internationally diversified portfolio. According to modern portfolio theory, a total risk is sub-divided into diversified and undiversified risk. A well-balanced portfolio is one where the diversifiable risk is reduced as much as possible. The most accepted argument has been developed on theoretical assumptions that firm takes advantage of the benefits of internationalization in foreign markets (Hymer, 1976; Caves, 2007). Firms with well-developed strong competencies in local markets can exploit the benefits of international market and consequently it is argued that the higher the level of internationalization of a firm, the higher would be the exploitation of tangible and intangible resources that are expected to boost productivity (Hymer, 1976).

In a study by Doaei and Shavazipour (2013) on manufacturing quoted companies in Malaysia stock exchange. The data of 102 firms were collected spanning 2006 to 2010 from the stock exchange in Malaysia. Six output variables and four input variables were selected using DEA methodology. By applying the input-oriented BCC model, the efficiency scores of 102 selected firms listed in Bursa Malaysia were calculated over the given period. As a result, only six DMUs (DMU 9, 12, 58, 59, 61 and 62) were efficient in all years. The result also showed that increasing in the product diversification and international diversification can leave a positive effect on efficiency and raise the corporation's efficiency score. Then, the improvement strategy has been suggested by slack analysis. Further analysis on the Malmquist productivity Index indicate that Bursa Malaysian experienced on average $88 \%$ productivity loss from 2006 to 2010. Decomposition of the MIP is described that a negative shift in frontier technology (about $88 \%$ ) is the only source of productivity loss and the overall $15.44 \%$ improvement in its technical efficiency could not rectify these huge productivity regressions.

Brighi and Venturelli (2013) examine the effects of revenue and geographic diversification on bank performance of Italian banks for the period 2006-2011. A panel regression econometric method was used to analyze the data. The central results suggest that revenue and geographical diversification play a role in determining bank performance. Their findings have implication for the diverse stakeholders (regulators, bank managers, investors and supervisors) in regards to banks' stability and performance.

Jouida, Bouzgarrou and Hellara (2017) in their study investigated the effects of activity and geographic diversification on performance: evidence from French financial institutions. The study examined 244 French financial institutions and observed a negative relationship between diversification and performance. Hence, this association is significantly positive when firms indulge in dual diversification policy.

Yildirim and Efthyvoulou (2018) analyze the effect of geographic diversification on bank value by using a data set sample period between 2004-2013. The system GMM estimator was used for the analysis. Their findings revealed that the value impact of international diversification depends on a bank's home country: higher levels of diversification are associated with changes in valuations only for banks originating from emerging countries.

\subsection{Theoretical Considerations}

This study is hinged on market power theory and the debate for market power surfaced from Porter (1980) opinion of positioning corporate firms and entities in their different 
environments by means of strategies sets that differentiates a firm's position from the rivals in business environment. In stifling competition, diversification is an indispensable strategy (Barney, 1991; 2002), it gives corporate firm the avenue to build market power, hencegranting it access to conglomerate powers. Firms are able to advance their competitive power in the market by venturing into other markets through diversification which includes foreign diversification. This is not because of their particular position in that market but because of their positions in their individual markets (Gribbin, 1976). This clout in the foremost market spurs the firm to penetrate new markets through grasping policies supported by its location, funds and power in its contemporary market. Firms can annex market power through diversification in three ways: cross subsidization by means of earnings from one market to shore upvoracious pricing in another; mutual forbearance of rigorous competition among competitors; and reciprocal buying among units of a multi-business firm which forecloses small competition (Montgomery, 1994). With this approach, firms are able to overcome competition thereby earning profits above the average market profits. As such, market power theory hypothesis a positive relationship between diversification and firm performance.

\section{Methodology and Model Specification}

This study used secondary data sourced and computed from the various audited financial statements of sampled deposit money banks (corporate diversification variables) in the selected countries over the period 2007 - 2017. A total of fifty (50) deposit money banks across eleven (11) Sub-Sahara African countries were used in this study (see appendix one). The choice of the eleven countries is based on their vibrant stock exchanges and compliant to voluntary sustainability report guidelines of the selected bourses.

This study employedpanel unit root analysis, co-integration test and the system- GMM. The panel unit root is to ascertain the stationarity and normality of the data in the variables in the specified model. Rationalization for the test of stationarity is to guarantee that the data are consistent for the system-GMM application. Thesystem Generalized Method of Moments became essential to solve the drawbacks of endogeneity of independent variables with dependent variable, omitted variables, measurement biases and heterogeneity problems associated with cross-country data.

\subsection{Model Specification}

The two models are anchored on the theoretical framework of market power theory (MPT) as earlier stated. In order to examine the impact of foreign diversification on performance of quoted deposit money banks, the model was adapted from Olarewaju, Migiro and Sibanda (2017) by incorporating a market base performance measure (Tobin Q).

The functional forms of the models are stated below;

$$
N I M_{i t-1}=f[F D, I N D, S D, B S I Z E, B A G E]
$$

$T O B I N Q_{i t-1}=f[F D, I N D, S D, B S I Z E, B A G E]$

The econometric forms of the models are stated below as;

$$
\begin{aligned}
& N I M_{i t-1}=\beta_{0}+\beta_{2} F D_{i t}+\beta_{1} I N D_{i t}+\beta_{3} S D_{i t}+\beta_{4} S I Z E_{i t}+\beta_{5} B A G E_{i t}+U_{t} \ldots \ldots \ldots \ldots \\
& \text { TOBINQ } Q_{i t-1}=\beta_{0}+\beta_{1} F D_{i t}+\beta_{2} I N D_{i t}+\beta_{3} S D_{i t}+\beta_{4} S I Z E_{i t}+\beta_{5} B A G E_{i t}+U_{t} \ldots .
\end{aligned}
$$

Where:

FD = Foreign diversification measured as Ln [1 + number of foreign subsidiaries $]$

IND = Income diversification is measured as the ratio of net interest income minus other operating income to total operating income deducted from one (1) 
$\mathrm{SD}=$ Subsidiary diversification measured as $\operatorname{Ln}[1+$ number of foreign subsidiaries + domestic subsidiaries]

BSIZE = Size of the Bank measured as Log (market value). Where market value is share price $x$ number of shares outstanding

BAGE = Age of the Bank is measured as the number of years from the day the firm was established till 2017.

$$
N I M=\frac{(\text { Investement Income }- \text { Interest Expenses) }}{\text { Average Earning Assets }}
$$

Tobin $Q=$ Tobin $Q$ is measured as the summation of market capitalization and total liabilities minus the net cash flow to total asset

Where irepresent countries in all sample and $t$ represents the scope or period of study.

$\beta_{0}-\beta_{5}$ are parameters to be estimated and $U_{t}$ is the error term.

\section{Analysis of Result}

From the Table of unit roots tests above, the levels variables (except SD-subsidiary diversification) are all significant in terms of the test statistics at either the 1 percent levels based on the LLC, IPS and ADF-Fisher tests. Only the Breitung test reports non-significant tests values for all the variables in levels. This shows that for all the variables (except SD) the null hypothesis of the stationarity cannot be rejected in levels, suggesting that the variables among the firms do not follow a defined pattern of movement over any given period.

Table 1: Panel Unit root test result

\begin{tabular}{|c|c|c|c|c|c|c|c|c|}
\hline & \multicolumn{4}{|c|}{$\begin{array}{l}\text { Homogeneous Unit Root } \\
\text { Process }\end{array}$} & \multicolumn{4}{|c|}{ Heterogeneous Unit Root Process } \\
\hline & \multicolumn{2}{|c|}{ Level } & \multicolumn{2}{|c|}{$1^{\text {st }}$ Diff } & \multicolumn{2}{|c|}{ Level } & \multicolumn{2}{|c|}{$1^{\text {st }}$ Diff } \\
\hline $\begin{array}{l}\text { Variable } \\
\text { s }\end{array}$ & LLC & $\begin{array}{l}\text { Breit } \\
\text { ung }\end{array}$ & LLC & $\begin{array}{c}\text { Breitu } \\
\text { ng }\end{array}$ & IPS & $\begin{array}{l}\text { ADF-F } \\
\text { isher }\end{array}$ & IPS & $\begin{array}{l}\text { ADF-F } \\
\text { isher }\end{array}$ \\
\hline NIM & $-29.5^{\star \star}$ & -1.17 & $-22.6^{\star \star}$ & $-6.03^{\star \star}$ & $-8.19^{\star \star}$ & $203.2^{\star \star}$ & $-9.39^{\star *}$ & $264.9^{\star \star}$ \\
\hline Tobin_Q & $-2.39^{\star \star}$ & -0.94 & $13.96^{\star *}$ & $-4.32^{\star \star}$ & $-2.39^{* \star}$ & $148.3^{\star \star}$ & $-7.84^{\star \star}$ & $247.3^{\star \star}$ \\
\hline IND & $-6.75^{* *}$ & -1.08 & $-15.4^{\star \star}$ & $-3.22^{* *}$ & $-2.42^{* *}$ & $151.2^{\star \star}$ & $-7.56^{* *}$ & $247.9^{* *}$ \\
\hline$F D$ & $-13.8^{* *}$ & -1.13 & $-7.49^{\star \star}$ & $-5.01^{* *}$ & $-2.18^{* *}$ & $51.1^{* *}$ & $59.9^{* *}$ & $97.9^{* *}$ \\
\hline$S D$ & -0.99 & -0.51 & $-7.95^{\star \star}$ & $-4.18^{* *}$ & 1.75 & 51.7 & $-3.27^{* *}$ & $109.6^{\star *}$ \\
\hline$S I Z E$ & $-8.11^{\star \star}$ & -1.02 & $-6.48^{* \star}$ & $-3.00^{* \star}$ & -0.89 & 117.5 & $-2.96^{* *}$ & $166.6^{\star *}$ \\
\hline
\end{tabular}

Note: ${ }^{*}$ and ${ }^{* *}$ indicate significance at 5 and 1 percent respectively.

Source: Author's computations

The variables are apparently not time dependent. However, the result also shows that for the first difference variables, all the test statistics are significant, thereby leading to the rejection of the null hypothesis of no unit roots in the first differences. These results strongly indicate that most of the variables are stationary both in level and at first differences. This finding is supported by both the homogenous and heterogeneous panel unit root tests. Since the variables are also stationary after first difference, we then proceed to establish their long run relationship below. 
Table 2: Cointegration Test Results

\begin{tabular}{|c|c|c|c|c|c|}
\hline \multicolumn{5}{|c|}{ Pedroni Residual Cointegration Test } & $\begin{array}{l}\text { Kao Residual } \\
\text { Test }\end{array}$ \\
\hline & Statistic & Weighted Statistics & & Statistics & \\
\hline \multicolumn{6}{|c|}{ NIM Equation } \\
\hline Panel v & $-15.66^{\star *}$ & $-11.62^{\star \star}$ & Group rho & $9.11^{* \star}$ & \multirow{4}{*}{$3.49^{* *}$} \\
\hline Panel rho & $20.34^{\star \star}$ & $14.72^{\star \star}$ & Group PP & $-12.18^{\star \star}$ & \\
\hline Panel PP & $-3.32^{* *}$ & $-7.38^{\star \star}$ & Group ADF & $-7.01^{* *}$ & \\
\hline Panel ADF & $-4.38^{\star *}$ & $-5.34^{* *}$ & & & \\
\hline \multicolumn{6}{|c|}{ Tobin Q Equation } \\
\hline Panel v & $5.12^{\star *}$ & $-9.01^{* *}$ & Group rho & $12.06^{\star *}$ & \multirow{4}{*}{$-3.07^{* *}$} \\
\hline Panel rho & $2.62^{\star \star}$ & $7.34^{\star \star}$ & Group PP & $-11.52^{\star *}$ & \\
\hline Panel PP & $-8.37^{* *}$ & $-9.21^{* *}$ & Group ADF & $-0.57^{* *}$ & \\
\hline Panel ADF & $3.55^{\star *}$ & $-3.19^{* \star}$ & & & \\
\hline
\end{tabular}

Note: ${ }^{*}$ and ${ }^{* *}$ indicate significance at 5 and 1 percent respectively.

Source: Author's computations, 2018

From the tests results, it can be seen that the tests based on Pedroni residual all report values that are significant at the 1 percent level for both the grouped and ungrouped tests. All test processes, including rho, PP and ADF are significant for both the within and between tests (at the 1 percent level). Thus, the null hypothesis of no co-integration is rejected for the combination of the variables, with each of the dependent variables.

Table 3: Sys-GMM Results for NIM

\begin{tabular}{|c|c|c|c|c|c|}
\hline Variable & 1 & 2 & 3 & 4 & 5 \\
\hline $\mathrm{NIM}_{\mathrm{t}-1}$ & $\begin{array}{l}0.378^{\star *} \\
(0.000)\end{array}$ & $\begin{array}{l}0.318^{\star \star} \\
(0.000)\end{array}$ & $\begin{array}{l}0.329 * * \\
(0.002)\end{array}$ & $\begin{array}{l}0.361^{\star *} \\
(0.000)\end{array}$ & $\begin{array}{l}0.377^{\star *} \\
(0.000)\end{array}$ \\
\hline Foreign diversification & . & $\begin{array}{l}-4.892 \\
(0.097)\end{array}$ & - & $\begin{array}{l}-7.772^{\star \star} \\
(0.000)\end{array}$ & $\begin{array}{l}-6.550^{\star *} \\
() .000)\end{array}$ \\
\hline Income diversification & $\begin{array}{l}1.323^{\star *} \\
(0.000)\end{array}$ & - & - & $\begin{array}{l}1.310^{\star *} \\
(0.000)\end{array}$ & $\begin{array}{l}1.180^{\star *} \\
(0.000)\end{array}$ \\
\hline Subsidiary diversification & - & - & $\begin{array}{l}4.773^{*} \\
(0.033)\end{array}$ & $\begin{array}{l}5.257^{*} \\
(0.036)\end{array}$ & $\begin{array}{l}6.069^{* *} \\
(0.003)\end{array}$ \\
\hline SIZE & $\begin{array}{l}-2.721 \\
(0.117)\end{array}$ & $\begin{array}{l}-9.369 \\
(0.271)\end{array}$ & $\begin{array}{l}-6.723^{\star *} \\
(0.002)\end{array}$ & - & $\begin{array}{l}-2.532 \\
(0.183)\end{array}$ \\
\hline BAGE & $\begin{array}{l}-0.142 \\
(0.483)\end{array}$ & $\begin{array}{l}-0.253^{*} \\
(0.026)\end{array}$ & $\begin{array}{l}-0.149 \\
(0.209)\end{array}$ & - & $\begin{array}{l}-0.182 \\
(0.101)\end{array}$ \\
\hline $\begin{array}{l}\text { Overidentifyingrestriction } \\
\text { (Hansen J-prob) }\end{array}$ & 0.172 & 0.354 & 0.402 & 0.238 & 0.194 \\
\hline Arrelano-Bond AR(1) & -1.69 & $-1.96^{*}$ & -1.60 & $-1.99^{*}$ & -1.49 \\
\hline Arrelano-Bond AR(2) & -0.24 & 0.44 & 0.27 & -0.17 & -0.01 \\
\hline No. of observations & 540 & 540 & 540 & 540 & 540 \\
\hline
\end{tabular}

Note: ${ }^{*}$ and ${ }^{* *}$ indicate significance at 5 and 1 percent respectively. T-probabilities in parentheses below each coefficient

Source: Author's computations, 2018 
The result of the estimates for net interest margin (NIM) as an indicator of bank performance are reported in Table 3 . The results also have impressive diagnostic indicators, with all the Hansen-J statistic probabilities in the region that suggest appropriate selection of instruments used for the GMM estimation. The Arrelano-Bond AR statistic for the first and second lags both show that the estimates are free from serial correlation for the panel variables in levels. The coefficient of the lagged dependent variable has the expected positive sign, which suggests long run equilibrium for NIM among the banks in the sample. The coefficient of the lagged dependent variable hovers around $0.31-0.37$ percent, which is relatively low and indicates that adjustment to long run equilibrium is slow. On the other hand, the results show that only the NIM (efficiency of fund investment by banks) has a positive lagged coefficient in the GMM estimates among the performance indicators, suggesting that only NIM adjusts to equilibrium level in the long term based on the effects of diversification and other factors.

The result shows that the coefficient of foreign diversification is negative for each of the estimates in the result. The coefficients also pass the significance tests at the 1 percent level, indicating that foreign diversification has significant debilitating effect on efficiency of funds investment among the banks in the African region. Increased foreign diversification reduces NIM for banks. Apparently, with higher foreign diversification, there appears to be losses in terms of efficiency of fund use as the banks grow wider. Like the result for the ROA estimates, the negative effect of foreign diversification on NIM intensifies when other aspects of diversification are taken into cognizance in the model.

Income diversification is also positive on NIM for each of the estimation structure. The coefficients are all high, and indicate that with increased income diversification, banks tend to enjoy better interest margins. The effect is relatively similar even when other diversification aspects are controlled in the model. This shows that it does not matter the other forms of diversification a bank involves in, income diversification tends to always improve NIM for the banks (which is a similar result to that of ROA). The coefficient of subsidiary diversification also passes the significance test at the 1 percent level for each of the estimation outputs, suggesting that higher subsidiary diversification leads to improvements in NIM by banks. The positive effects are higher when other diversifications are included in the estimates. Thus, the dichotomy of the effects of diversification on NIM runs in the line of foreign or domestic diversification. The two domestic diversification variables have significant positive impacts on NIM but the foreign diversification variable has a negative effect on NIM. The coefficients of size and age are mainly insignificant in the results (especially the full estimates), suggesting that neither bank size not age has significant impact on the capacity of banks to invest funds more efficiently

Table 4: Sys-GMM Results for Tobin's $Q$

\begin{tabular}{|c|c|c|c|c|c|}
\hline Variable & 1 & 2 & 3 & 4 & 5 \\
\hline TOBIN_Q Qt-1 & $\begin{array}{c}-0.031^{\star *} \\
(0.000)\end{array}$ & $\begin{array}{c}-0.014^{\star \star} \\
(0.000)\end{array}$ & $\begin{array}{c}-0.066^{* *} \\
(0.000)\end{array}$ & $\begin{array}{c}-0.095^{* *} \\
(0.000)\end{array}$ & $\begin{array}{c}-0.055^{\star *} \\
(0.000)\end{array}$ \\
\hline Foreign diversification & & $\begin{array}{c}-0.808^{\star *} \\
(0.000)\end{array}$ & & $\begin{array}{l}1.031^{* *} \\
(0.000)\end{array}$ & $\begin{array}{c}-2.325^{\star *} \\
(0.000)\end{array}$ \\
\hline Income diversification & $\begin{array}{c}-0.044^{\star \star} \\
(0.002)\end{array}$ & & & $\begin{array}{c}-0.424^{\star \star} \\
(0.000)\end{array}$ & $\begin{array}{l}0.447^{\star \star} \\
(0.000)\end{array}$ \\
\hline Subsidiary diversification & & & $\begin{array}{c}-0.941^{* *} \\
(0.000)\end{array}$ & $\begin{array}{c}-0.675^{\star *} \\
(0.002)\end{array}$ & $\begin{array}{c}-9.423^{* *} \\
(0.002)\end{array}$ \\
\hline SIZE & $\begin{array}{l}1.667^{* *} \\
(0.001)\end{array}$ & $\begin{array}{l}2.169^{* *} \\
(0.003)\end{array}$ & $\begin{array}{l}2.205^{* *} \\
(0.001)\end{array}$ & & $\begin{array}{l}2.418^{* *} \\
(0.001)\end{array}$ \\
\hline
\end{tabular}




\begin{tabular}{|l|c|c|c|c|c|}
\hline BAGE & $\begin{array}{c}-0.156^{* *} \\
(0.000)\end{array}$ & $\begin{array}{c}-0.194^{* *} \\
(0.000)\end{array}$ & $\begin{array}{c}-0.189^{* *} \\
(0.000)\end{array}$ & & $\begin{array}{c}-2.028^{* *} \\
(0.004)\end{array}$ \\
\hline $\begin{array}{l}\text { Overidentifying restriction } \\
\text { (Hansen J-prob) }\end{array}$ & 0.387 & 0.461 & 0.424 & 0.491 & 0.302 \\
\hline Arrelano-Bond AR(1) & $-2.03^{\star}$ & $-1.94^{\star}$ & $-2.00^{\star}$ & -1.83 & $-1.91^{*}$ \\
\hline Arrelano-Bond AR(2) & 0.73 & -0.74 & -0.80 & 0.92 & -0.77 \\
\hline No. of observations & 540 & 540 & 540 & 540 & 540 \\
\hline
\end{tabular}

Note: ${ }^{*}$ and ${ }^{* *}$ indicate significance at 5 and 1 percent respectively. T-probabilities in parentheses below each coefficient.

Source: Author's computations, 2018

This measure of bank performance in the analysis is Tobin's $Q$ which relates to the performance in terms of the stock market. The diagnostic tests in the results are also impressive based on the Hansen J-test and the Arrelano-Bond AR tests. The coefficient of the over-identifying restriction test statistic for the GMM estimates possess the expected values (i.e. greater than 0.1 ), indicating that the instruments used in the estimation are valid. The Arrelano and Bonds first and second order serial correlation tests also possess the expected outcomes. The tests show that the first order statistic is statistically significant and has the expected negative sign. The second order statistic is not significant (in line with aprioriexpectation), suggesting that the model error terms are serial uncorrelated in levels. This provides additional support for the instrument's validity test indicated by the Hansen J-statistic.

From the result, the coefficient of foreign diversification is essentially negative for the results with control or without control for other diversification factors. This implies that foreign diversification actually leads to reduction of the banks' Tobin $Q$ value across the countries. This result is actually surprising since increased foreign participation in the foreign sector should boost investors' confidence among the banks. What the results reveal however is that with increased foreign participation, banks tend loose competitive advantage in terms of improving market value. Again, using Net interest margin (NIM) and Tobin Q as performance indicator, foreign diversification showed a significant discounted relationship with the aforementioned dependent variables. These findings are in line with the studies of Sammehetal (2017), Jouida and Hellara (2017), Estes (2014) and Berger and Ofek (1995). The implication of these mixed findings is that with increased foreign participation, quoted deposit money banks tend loose competitive advantage in terms of improving their respective market values across selected Sub-Sahara African countries in the sample. This can also give credence to the fact that majority of the stock exchanges apart from Johannesburg stock exchange and Nigeria stock exchange are still in their infantile stages in regards to volume and value of trade that takes place in their respective floors owing to the depth and breadth of their markets.

Income diversification has a unique pattern of effects on firms' performance in terms of Tobins $Q$. On its own, the effect is negative but with other diversification, the effect is positive (with no control for size and age) and positive (with control for size and age). This implies that income diversification will only have positive impact on Tobin $Q$ when the banks also have foreign and subsidiary diversification and for older and larger banks. Since income diversification tends to improve the performance of the banks in the stock market through expanding financial capacities of the banks, other forms of expansion are likely to make these effects more stable.

The coefficient of subsidiary diversification is also negative all through the different estimates and significant at the 1 percent level. This shows that subsidiary diversification also tends to reduce Tobins Q. Again, this does not seem to agree with apriori expectations since more subsidiaries should improve the value of the banks through expansion of asset 
base. However, these results reveal that for banks in Africa, subsidiary diversification would tend to depreciate the banks' market value. The coefficient of bank size was significant in each of the estimates, suggesting that larger banks have better higher market value than smaller banks. On the other hand, older banks do not have higher market value than younger counterparts as demonstrated by the negative coefficients of the BAGE variable. Foreign diversification does not significantly impact on performance of quoted deposit money banks in selected Sub-Sahara African countries.

From the results of the GMM estimates, the coefficient of foreign diversification passed the significance test in each estimation at the 1 percent level since the associated probabilities with the individual $t$-values are all less than 0.01 . Based on these results, the null hypothesis is rejected in this case and a significant impact is demonstrated from foreign diversification of the banks on their performance. The direction of the impact is however not linear as shown in the estimates.

\section{Concluding Remarks and Recommendations}

Foreign diversification of deposit money banks has been embraced by most banks and has taken the center stage of most economies in the world. This is so because it helps in building a virile, efficient and robust banking system which can spark the performance of the individual banks and lead to the overall growth of the various national economies. In order to gain extensively from the gains of foreign diversification, regulatory authorities of SSA countries should put in place different institutional reforms that will help in carrying out banking activities within the SSA regions with little or no stringent rules that can help deposit money banks to operate in the different financial markets.

The regulatory agencies within each of the countries in the region should also consider providing enabling environment for encouraging intra-regional foreign diversification of banks. The study has suggested that banks tend to lose certain competitive efficiency when they involve in foreign diversification, this can be reduced when environments are conducive for region-based banks to interact with financial markets of other countries within the region. Furthermore, the impact of foreign diversification was negative in all the estimation results. This suggests that most banks are yet to adopt credible foreign diversification strategies that will yield positive performance outcomes. Some of the banks are likely to be operating with toxic assets of foreign enterprises and as a result, unable to perform financially. It is therefore necessary for these banks to engage in proper environmental scanning and assets monitoring in order to ensure that, their investments go into proper channels in the foreign domain.

This study is limited by focusing on just one method of data analysis (System GMM). Further studies on corporate diversification and banks performance should utilize other econometric techniques like Panel Vector Auto regressive (PVAR) and Panel Vector Error Correction Model (PVECM) to examine the effect of the relationship so that the outcome will be more robust and encompassing.

\section{References}

Ansoff, H. I. 1957. Strategies for diversification. Harvard Business Review, 35, pp.113-124. Barney, J. 1991. Firm resources and sustained competitive advantage. Journal of Management, 17 (1), pp. 99-120

Barney, J. 2002. Gaining and sustaining competitive advantage. Second edition, Prentice Hall.

Berg, J.V. 2016. Corporate diversification and firm performance: The effect of the global financial crisis on diversification in India. Being a master's thesis submitted to the department of business administration, University of Groningen. 
Berger, P. G. and Ofek, E. 1995.Diversification's effect on firm value. Journal of Financial Economics, 37 (1), pp. 39-65.

Brighi, P. and Venturelli, V. 2013. How do income diversification, firm size and capital ratio affect performance? Evidence for bank holding companies. Applied Financial Economics, 24 (21), pp. 1375-1392

Buhner, R. 1987. Assessing international diversification of west German corporations. Strategic Management Journal, 8(1), 25-37

Capar, N. and Kotabe, M. 2013. The relationship between international diversification and performance in service firms. Journal of International Business Studies, 34 (4), pp.345-355 Caves, R.E. 1971. International Corporations: The Industrial economics of foreign investment. Economica, 38 (February), pp. 1-27.

Charnes, A., Cooper, W. and Rhodes, E. 1978. Measuring the efficiency of decision making units. European Journal of Operational Research, 2, pp. 429-444

Chen, Y., Wei, X., Zhang, L. and Shi, Y. 2013.Sectoral diversification and the banks' return and risk: evidence from Chinese listed commercial banks. Procedia Computer Science, 18, pp. 1737-1746.

Doaei, M. and Shavazipour, B. 2013. Corporate diversification's effects on efficiency and productivity: case study of manufacturing firms listed in Bursa Malaysia. International Journal of Business and Development Studies, 5 (1), pp. 77-96.

Estes, K. 2014. Diversification and community bank performance during a financial crisis. International Journal of Finance \& Banking Studies, 3 (4), pp. 1-40.

Feng, C.; Wang, H.; Lu, N.; Chen, T.; He, H.; Lu, Y. and Tu, X. 2014.Log-transformation and its implications for data analysis. Shanghai Archives Psychiatry, 26(2), pp. 105-109

Gamra, S.B. and Plihon, D. 2011. Revenue diversification in emerging banks: Implications for financial performance. CEPN working papers.

Gribbin, J.D. 1976. The conglomerate merger, Applied Economics, 8, $19-35$.

Hymer, S. H. 1976. The international operations of national firms; $A$ case study of foreign investment. Cambridge, Mass: MIT Press.

Jouida, S. and Hellara, S. 2017. Diversification, capital structure, and performance: A simultaneous equation approach. Manage Decision Economics, 2, pp. 1-14.

Jouida, S., Bouzgarrou, H. and Hellara, S. 2017. The effects of activity and geographic diversification on performance: Evidence from French financial institutions. Research in International Business and Finance, Elsevier, 39, pp. 920-939.

Krivokapic, R., Njegomir, V. and Stojic, D. 2017. Effects of corporate diversification on firm performance: evidence from the Serbian insurance industry. Economic Research-Ekonomskalstraživanja, 30 (1), pp. 1-13.

Montgomery, C. A. 1994. Corporate diversification. Journal of Economic Perspectives, 8 (3), pp. 163-178.

Mulwa, J.M., Tarus, D. and Kosgei, D. 2015. Commercial bank diversification: A theoretical survey. International Journal of Research in Management \& Business Studies, 2 (1), pp. 27-32.

Mulwa, J.M and Kosgei, D. 2016. Commercial bank diversification and financial performance: the moderating role of risk. Journal of Finance and Investment Analysis, 5 $(2,3)$, pp. 28-43.

Ojo, O. 2009.Corporate diversification and firm performance. Manager: Current Economic Crisis, 9, pp. 39-51

Ojo, O. 2011. An appraisal of the practice of corporate diversification in selected Nigerian banks. Management science letters, 1 (3), 295-306.

Olarewaju, O.M., Migiro, S.O. and Sibanda, M. 2017. Operational diversification and financial performance of sub-Saharan Africa commercial banks: Static and dynamic approach. Economica, 13 (5), pp. 84-106. 
Thomson, A.A., Gamble, J.E. and Strickland, A.J. 2004.Crafting and Executing Strategy: The Quest for Competitive Advantage - Concepts and Cases. McGraw-Hill/Irwin.

Turkmen, S.Y. and Yigit, I., 2012. Diversification in banking and its effect on bank performance: Evidence from Turkey. American International Journal of Contemporary Research, 2 (12), pp. 110-119

Ugwuanyi, G.O. and Ugwu, J.N. 2012.The effect of corporate diversification on the profitability of the financial services sector in Nigeria. International Scholarly and Scientific Research \& Innovation, 6 (7), pp. $78-83$.

Yildirim, C. and Efthyvoulou, G. 2018. Bank value and geographic diversification: Regional vs Global. Journal of Financial Stability, 36, pp. $225-245$.

\section{Bio-note}

Osifo Osagie is a lecturer with the department of Banking and Finance in the prestigious University of Benin, Nigeria. He holds B. Sc in Banking and Finance, M.Sc in Finance and Ph.D in Finance all from University of Benin. He has published in reputable journals both in Nigeria and international.

Evbayiro-Osagie Esther Ikavbo is currently the head of department of Banking and Finance, University of Benin, Benin City. She holds a B.Sc in Business Administration (First class honours), M. Sc in Finance and Ph.D in Financial Management all from University of Benin. She has attended numerous academic conferences; she has published in learned academic journals both foreign and local. 
APPENDIX 1: Sample of Selected Banks in SSA

\begin{tabular}{|c|c|c|}
\hline $\mathbf{S} / \mathbf{N}$ & Company & COUNTRY \\
\hline 1 & First National Bank Botswana & Botswana \\
\hline 2 & Barclays Bank Botswana & Botswana \\
\hline 3 & Stand Chartered Botswana & Botswana \\
\hline 4 & Lethego holdings & Botwana \\
\hline 5 & Ecobank Transnational Inc & Ghana \\
\hline 6 & Standard Chartered Bank Ghana & Ghana \\
\hline 7 & Ghana Commercial Bank & Ghana \\
\hline 8 & Cal Bank & Ghana \\
\hline 9 & Societe General Ghana & Ghana \\
\hline 10 & Hfc Bank Ghana & Ghana \\
\hline 11 & Equity Group Holdings & Kenya \\
\hline 12 & Kenya Commercial Bank & Kenya \\
\hline 13 & Standard Chartered Bank Kenya & Kenya \\
\hline 14 & Barclays Bank Of Kenya & Kenya \\
\hline 15 & Diamond Trust Bank Kenya & Kenya \\
\hline 16 & Cfc Stanbic Of Kenya & Kenya \\
\hline 17 & Nic Bank & Kenya \\
\hline 18 & Cooperative Bank of Kenya & Kenya \\
\hline 19 & National Bank Of Kenya & Kenya \\
\hline 20 & Standard Bank Malawi & Malawi \\
\hline 21 & First Merchant Bank & Malawi \\
\hline 22 & Nbs Bank Malawi & Malawi \\
\hline 23 & National Bank of Malawi & Malawi \\
\hline 24 & SBM Holdings & Mauritius \\
\hline 25 & Fnb Namibia Holdings & Namibia \\
\hline 26 & Guaranty Trust Bank & Nigeria \\
\hline 27 & Zenith Bank & Nigeria \\
\hline 28 & Access Bank & Nigeria \\
\hline 29 & United Bank For Africa & Nigeria \\
\hline 30 & Stanbic lbtc Holding & Nigeria \\
\hline 31 & First Bank Holding & Nigeria \\
\hline 32 & Fidelity Bank & Nigeria \\
\hline 33 & Sterling Bank & Nigeria \\
\hline 34 & First City Monumental Bank & Nigeria \\
\hline 35 & Diamond Bank & Nigeria \\
\hline 36 & Wema Bank & Nigeria \\
\hline 37 & Union Bank & Nigeria \\
\hline 38 & Standard Bank Group & South Africa \\
\hline 39 & Firstrand & South Africa \\
\hline 40 & Barclays Africa Group (Absa Bank) & South Africa \\
\hline 41 & Nedbank Group & South Africa \\
\hline 42 & Capitec Bank Holdings & South Africa \\
\hline 43 & Stanbic Bank Uganda & Uganda \\
\hline 44 & Development Finance Uganda & Uganda \\
\hline 45 & Bank of Baroda & Uganda \\
\hline 46 & Standard Chartered Bank Zambia & Zambia \\
\hline 47 & Investrust Bank & Zambia \\
\hline 48 & Zambia National Commercial Bank & Zambia \\
\hline 49 & Cbz Holdings & Zimbabwe \\
\hline 50 & Fbc Holdings & Zimbabwe \\
\hline
\end{tabular}

Source: Author's compilation, 2018. 